\title{
Korea's Reunification from the Perspective of Northeast Asia's Economic Integration
}

\author{
Il-Dong Koh \\ Director, Center for the North Korean Economy
}

\section{Introduction}

In the Post Cold War Era, no other region has shown such a high level of economic dynamism as Northeast Asia. This can be ascribed to China's economic rise and a rapid expansion of intra-regional economic exchanges and cooperation, i.e., there has been continued expansion and deepening in the division of labor among Northeast Asian countries, particularly with the explosive growth of the Chinese economy.

In spite of its proximity to China, however, North Korea has been forgoing all economic possibilities as a consequence of its own political decision to shun globalization and regional cooperation. It is astonishing that North Korea still remains as a poverty pocket in the dynamic Northeast Asian region.

Being an enclave right in the middle of the most dynamic region in the world, North Korea cannot maintain its present position for an extended period. Its internal outcry and external demand to open its gate can hardly be suppressed with a political oppression and reclusive policy. At the same time, it is still an open question what path North Korea will take in the event of its escape from the poverty pocket and join the international division of labor.

The prospects for a unified Korean economy is diverse, ranging from a gloomy picture of double collapse as a consequence of the huge burden of unification to a rosy picture of becoming a global middle power in several decades. In fact, Korea's reunification involves a variety of risk factors as well as diverse opportunities,

\footnotetext{
*Corresponding address: Dr. Il-Dong Koh; Director, Center for the North Korean Economy, Korea Development Institute, E-mail: idkoh@kdi.re.kr

(C)2012-Center for Economic Integration, Sejong Institution, Sejong University, All Rights Reserved.
} 
depending upon the path taken by the two Koreas during the course of actual reunification.

We can imagine a variety of unification scenarios depending upon its final outcome, such as the best scenario, the worst scenario, and the most probable one. All these different scenarios entail specific preparations in the future. While the worst scenario would require the construction of a contingency plan, the best scenario, a visionary one and the most probable one, would compel a depiction of a desirable environment in the future. For the following discussion, we would adopt a hybrid of the best scenarios and the most probable ones. Also, in order to make our discussion simple, a unitary state is assumed to be the final governmental structure of the unified Korea even if the final outcome would be path-dependent and the process will substantially determine the end-point state.

\section{Economic Benefits from the Unification}

\section{A. The immediate economic benefits for the two Koreas}

Once the two Koreas are unified, the immediate economic benefit would be realized from the apparent differences in resource endowments between them. The cash-strapped and technology-deficient North Korea can tremendously benefit from the external supply of capital and technology coming from South Korea as well as from other neighboring countries.

On the other hand, the South Korean economy would greatly benefit from North Korea's relatively abundant labor, land, and natural resources, including its various mineral reserves. In addition, North Korea's relatively inexpensive labor can help prevent the hollowing-out of manufacturing sectors in the South Korean economy.

Table 1. Forcast of North and South Korea's Demography (unit: \% in each region in each specific year)

\begin{tabular}{ccccccc}
\hline Age & \multicolumn{2}{c}{$0-14$ years } & \multicolumn{2}{c}{$15-64$ years } & \multicolumn{2}{c}{ over 65 } \\
& South & North & South & North & South & North \\
& Korea & Korea & Korea & Korea & Korea & Korea \\
\hline 2010 & 16.2 & 21.2 & 72.8 & 69.0 & 11.0 & 9.8 \\
2020 & 13.3 & 19.0 & 71.2 & 71.3 & 15.4 & 9.7 \\
2030 & 12.6 & 18.7 & 64.2 & 68.9 & 23.2 & 12.4 \\
2040 & 11.4 & 16.6 & 54.4 & 65.3 & 34.2 & 18.1 \\
\hline
\end{tabular}

Source; UN, World Population Prospects: The 2008 Revision, 2009. 
All the more important is that North Korea's relatively young demographic structure can compensate for South Korea's aging population which has grown at an unprecedented level.

The under-utilized North Korean land mass can be employed for much higher value-adding activities with the introduction of external capital from the South and other countries. In relation, the huge land belt along the demilitarized zone that runs through the central part of the Korean peninsula will be put into use for more productive and environmental-friendly civilian purposes.

North Korea's abundant mineral resources represent another potential for the development of a unified Korean economy. North Korea's advantage in its mineral wealth lies not only in its abundance but also in its diversity. Taking into account that natural resource-deficient South Korea has to import most of those minerals, endowments of those resources lying under North Korea will lay another foundation for the development of unified Korea's related industry.

Of course, these mineral resources can be developed in the pre-unification era if substantial progress in North Korea's investment environments is to be made, with a proper provision of legal and institutional arrangements as well as physical infrastructures. But, a heavy reliance on the export of minerals would accompany the "curse of natural resources," driving down the price competitiveness of manufactured products as the result of domestic currency appreciation. This means that benefits from the development of North Korea's mineral industry can be maximized if it is paralleled with South Korea's manufactured product exports.

\section{B. Geo-economic picture in the post-unification era}

When the unification is realized, of course, the Korean people will become its immediate beneficiary. In addition to huge peace dividends and economic benefits aforementioned, various other economic benefits would also readily be available.

Unification of the Korean peninsula will obviously bring about a new geoeconomic order to Northeast Asia, influencing the interest of neighboring countries. It is also important to note that Korea's unification would not hurt anyone's interest in that it will accompany a genuine Pareto-efficient improvement that leaves all related parties better off. Neighboring countries can share the benefit of peace dividends as well as positive consequences of Korea's unification with the Korean people.

Under the state of national division, the geo-economic conditions of South Korea, being severed from the Asian continent, has been nothing more than an 
island which we have used for decades. Thus, the unification will remove a major stumbling block that has hindered Korea's economic cooperation with the Asian continent in such areas as electric power and energy network, transportation system, etc. and vice versa.

In the transportation area, the unification would allow trans-Korean railway system to be connected to trans-Siberian as well as trans-China railway system, which would shorten the economic distance between Korea and the European continent. Also the extension of Asian Highway network to the Korean peninsula would substantially improve Korea's accessibility to every corner of the Asian continent.

Economic benefits that can be expected from the connection of energy network and power grid would be far-reaching. Gas and oil pipelines from Siberia would bring about huge economic benefits not only for the Korean people, but also for an exporting country, as well as other neighboring countries. For example, the connection of unified Korea's power grid to that of Russian Far East can guarantee substantial efficiency gains from the exploitation of under-utilized electric power reserves in Russia.

\section{Growth potential of unified Korea}

Considering the huge economic gap between North and South Korea, which has been aggravated as the result of North Korea's two-decade long economic setback, redress of regional disparity will become one of the most difficult socio-economic tasks of the unified government. The history of economic development clearly indicates that an independent economic unit can hardly maintain more than $10 \%$ of annual GDP growth rate for an extended period.

The implication of this finding is that if Korea is to be united on the basis of the

Table 2. GDP Growth Rates of (Former) Socialist States

\begin{tabular}{ccc} 
& & (unit: \%) \\
\hline Country & Period & Average annual GDP growth rate \\
\hline China & $1979-2008$ & 9.83 \\
Vietnam & $1985-2008$ & 6.84 \\
Hungary & $1994-2008$ & 3.44 \\
Poland & $1995-2008$ & 4.81 \\
former East Germany & $1992-2004$ & 2.87 \\
\hline
\end{tabular}

Source: World Bank, World Development Indicators, various years 
Table 3. Income Disparity between North and South Korea

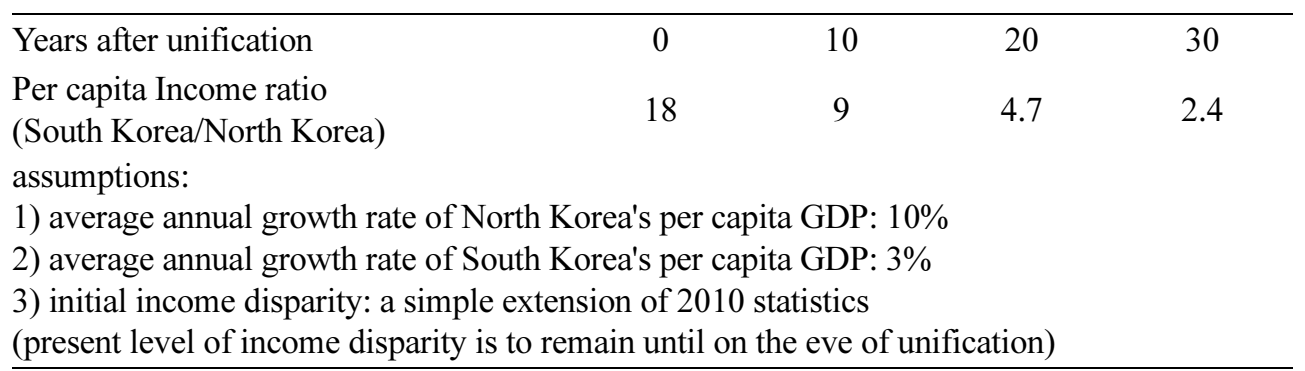

current level of income disparity, it will take more than 25 years for the North to catch up with South Korea in terms of per capita GDP within the range of 3:1. This means that economic conditions in North Korea would become much worse than that of former East Germany and the result will mean greater unification costs. Also, it is highly likely that North Korea will become another rising star in the world economic history.

The growth pattern in North Korea would become very uneven and dynamic depending on locational variance. The development of each region in North Korea would not follow a gradual pattern of development such that only a certain region of North Korea would duplicate some cities or industrial complexes of South Korea acting as growth poles. Under such circumstances, its productivity improvement could follow the leapfrog pattern and not a gradual catch-up process.

Also, North Korea's present weak points can be another springboard for its expeditious economic development. North Korea is saddled with two critical constraints: over-militarization and strictly closed economic system. A removal of these constraints will work as new stepping stones for a swift transformation and development of the North Korean economy.

Displacement of more than one million military personnel, who are mostly at their most productive ages, and diversion of military spending, which is estimated to be over $30 \%$ of its national income, would be new sources of its economic potential. In addition, relaxation of North Korea's long-suppressed external economic relations would guarantee a maximization of its geo-economic advantage with a swift integration like the regional division of labor in Asia. 
Korea's Reunification from the Perspective of Northeast Asia's Economic Integration 279

\section{The Implication of Korea's Unification for Regional Economic Integration}

While European integration has been driven by strong political will with a creation of supra-national institutions, economic integration in East Asia was essentially market-led. It is only after the Asian financial crisis that East Asia started to supplement market-led integration with various official schemes to promote regional integration. By and large, Northeast Asia is as interdependent in trade as Europe and North America.

The traditional production networks in Northeast Asia were triangular where Japan and Korea exported component parts to China which completed the processing and exported the final products to markets in the US and Europe. Since the mid-1990s, Northeast Asia's production networks have become more sophisticated and complex with the deepening of vertical integration, which makes a stark contrast with Europe where industrial structures are more homogeneous and less vertically integrated.

Even though the Asian economic integration, so far, has not been driven by political decision to unify the region, this type of international division of labor among regional countries naturally calls for institutional arrangements for higher level of policy coordination.

Given that Korea's national division has been the greatest impediment to the economic cooperation of Northeast Asia, the unification of North and South Korea will lay a firm ground for a speedy integration of the regional economy.

Of course, there are some parallels between Germany and Korea in the meaning of their unification. As German unification has been viewed as part of the European integration, Korean unification will also become an essential part of the economic integration of Northeast Asia.

But, in the context of regional economic integration, Korea's unification has more far-reaching implication. The process of European integration has proceeded without the precondition of German unification, although the two incidences coincided. In Northeast Asia, any meaningful improvement of regional integration can hardly be carried out without a resolution to problems arising from North Korea. There lies the need of Korea's unification in the framework of international cooperation and integration.

Received 1 December 2011, Accepted 15 April 2012 